\title{
Are the current On-site Stormwater Detention (OSD) policies the best solution for source control stormwater management? A case study of Australian and Brazilian cities
}

\author{
In recent decades On-site Stormwater Detention (OSD) systems have been \\ implemented in many cities around the world. However, a few studies have \\ evaluated the effectiveness of OSD policies. Therefore, this paper compared the \\ use of OSD in Australian and Brazilian cities, evaluating aspects of regulations, \\ technical details and management matters. The results showed that Australian OSD \\ design guidelines are a few steps ahead of Brazilian manuals. However, it is not \\ possible to affirm that the catchment-based approach, adopted by most Australian \\ councils, is better than the site-based approach, embraced by Brazilian cities, since \\ neither is supported by monitoring data of real OSD performance. In general, all \\ municipalities have the same management problems. There is no control over the \\ number of OSDs built in the cities or even the conditions of the systems. Thus, the \\ authors proposed some directions on how OSD performance could be better \\ evaluated.
}

Keywords: On-site Stormwater Detention (OSD), source control techniques, urban drainage management

\section{Introduction:}

Flooding and other urban drainage problems affect cities all over the world. The urbanization increase changes the hydrologic cycle and the flow regime of watershed streams, increasing runoff, reducing water infiltration, causing erosion and scouring of instream habitats, polluting and decreasing the aquatic biodiversity (Fletcher et al. 2013). In the 1970's, according to Baptista et al. (2005), a new approach emerged to treat urban drainage problems and seek to neutralize the effects of urbanization, promoting increased infiltration, evapotranspiration, storage, the use of rainwater and its treatment in urban areas. 
This approach has been known by different terms, as Low Impact Development LID, Sustainable Urban Drainage Systems - SUDS, Water Sensitive Urban Design WSUD, Best Management Practices - BMPs, Stormwater control measures - SCMs, Alternative Techniques, Source Control - SC and Green Infrastructure - GI. All terms are generally underpinned by two broad principles: (i) mitigation of changes to hydrology and evolution towards a flow regime as much as feasible towards natural levels or local environmental objectives, (ii) improvement of water quality and a reduction of pollutants. To achieve these principles, there are a range of structural and non-structural techniques that can be used in a catchment or a lot scale (Fletcher et al., 2014)

To improve the management of urban drainage systems, many cities have deployed policies related to stormwater source control for new developments, especially requiring the construction of On-site Stormwater Detention - OSD (Tsuchiya, 1978, Urbonas \& Glidden, 1983, Kelly \& Brinck, 1987, O’Loughlin et al., 1995, Faulkner, 1999, Silveri \& Rigby, 2006, Drumond et al., 2011, Petrucci et al., 2013). The concept of OSD technique is to promote the detention of additional stormwater runoff caused by impervious areas, in order to maintain the peak flow the same as the pre-urbanization condition. The use of OSD assist to achieve only the first principle cited by Fletcher et al. (2014), focusing in stormwater quantity management.

Among the studies related to the OSD theoretical simulations, the majority of research evaluated the efficiency of the peak flow damping in a lot scale (Tsuchiya, 1978; Cruz et al., 1998; Konrad \& Burges, 2001; Todeschini et al., 2012; Drumond et al., 2014; Ronalds \& Zhang, 2017). Despite there have been studies on OSD since the 1970s, there are not many experiments conducted in a real scale. The few researches that measured OSD real performance (Schilling, 1982; Agra, 2001; Campos, 2007; Cabral et al., 2009; and Petrucci et al., 2010) observed a good efficiency of peak flow reduction. Piel et al. 
(1999) have found that the lack of maintenance is the main cause for low performance of OSD. Drumond et al. (2018) monitored two OSDs built in Belo Horizonte and compared the maximum water levels data with theoretical simulations. The results showed that theoretical simulations presented lower values than those monitored.

According to McCuen (1979), Emerson et al. (2005), Goff \& Gentry (2006), in rare cases, detention structures may cause the increase of peak flows downstream. However, other researchers (Sugio et al., 1995; Tassi, 2002; Drumond, 2012; Da Silva \& Cabral, 2014) have indicated a considerable peak outflow reduction in the catchment in simulations using OSD.

As described by O'Loughlin et al. (1998), many papers on OSD were published in 1990's. However, source control techniques related to stormwater quality have come to the forefront and OSD has been relegated to the background. One possible reason for this is the change of stormwater management approach over recent decades in developed countries. Nowadays, the picture remains the same and this fact can be confirmed in the review of modeling/monitoring studies on the hydrologic effects of stormwater control measures made by $\mathrm{Li}$ et al. (2017). Nevertheless, OSD continues to be widely implemented and its real efficiency continues to be unknown due to the lack research, especially in the case of data monitoring.

In Brazil, the first urban drainage source control policy was created in the 1990's, by Belo Horizonte's municipality. The regulation demanded the employ of OSD for new developments with large impervious area. After that, other Brazilian cities also developed regulations imposing the use of OSD. However, these policies have different approaches to require OSD construction, regarding the cases of exemptions, incentives in the use of another source control techniques and methods to determine the maximum site discharge. 
According to O'Loughlin et al. (1995), in Australia, a country with similar climate conditions as Brazil, OSD was first adopted in the early 1980's by the Ku-ring-gai Council (Sydney's northern suburbs) and the Wollongong City Council. O'Loughlin et al. (1995 \& 1998) assessed OSD policies in Sydney councils and described typical OSD installations, town planning issues, the form of regulations, maintenance problems and indicated alternatives to improve the systems.

In order to evaluate the current scenario of OSD regulations, it was decided to compare the policies in Australia, a country considered experienced in the use of this technique, and in Brazil, where OSD adoption has been increasing. Thus, the purpose of this paper is to evaluate the current OSD policies in Brazil and Australia, highlighting the differences between regulations, technical details and management matters, and introduce ways on how OSD performance could be better evaluated. The OSD policies comparison across countries has never been made before.

\section{Material and Methods}

\section{OSD Policies Evaluated}

In Brazil, there are no national guidelines or Federal regulations on stormwater management, requiring the application of stormwater source control techniques. The main regulations related to this theme are in the municipal level.

Belo Horizonte was the first city in Brazil to create an OSD policy, demanding its application in municipal law $(7,166 / 96)$. Other Brazilian cities, including São Paulo, Rio de Janeiro and Curitiba also developed legislations imposing the use of OSD.

In 2006, a Porto Alegre specific legislation was created (Municipal Ordinance 15,371/06) to manage urban drainage flows. In a comparison among Brazilian municipalities, the Porto Alegre OSD policy was considered by Drumond et al. (2011) as 
the most restrictive in Brazil, demanding up to 7 times larger detention volumes than the requirements of Belo Horizonte's policy.

In Australia, OSD policy has been based on local regulations. Most Development Control Plans (DCPs) details the stormwater source control policy adopted by the municipality. Sydney Metropolitan Area was composed by 38 municipal councils and each has its own OSD regulation. Recently, the number of municipal councils was reduced with the announcement of mergers. However, in this study was considered the situation before fusion and the 38 OSD policies were assessed.

As described previously, OSD was first adopted by the Ku-ring-gai Council in Sydney and the Wollongong City Council (O’Loughlin et al. 1995). In 1999, during an OSD policy review in Wollongong City, the major issues raised by the community were related to exempt cases, development approval processes, philosophy, design criteria and maintenance responsibility. At this time, OSD policies from other Sydney councils were evaluated, as Upper Parramatta River Catchment Trust - UPRCT had the most detailed and stringent requirements, Wollongong City Council initially adopted as the basis for its own strategy (Silveri \& Rigby, 2006).

Thus, it was decided to compare the OSD policies between Australian and Brazilian cities, considering they have similar rainfall characteristics. There were selected for analysis the first municipalities to adopt OSD in their respective countries, Wollongong and Belo Horizonte, and the cities where these policies are references in their countries, Sydney and Porto Alegre. In a comparison among the rainfall intensities with durations of 10, 15, 30, 60, 120 and 180 minutes for rainfall intensities of 100 years ARI, a similar values of rainfall intensities can be observed, as show in Figure 1, especially in storm bursts greater than 15 minutes. 


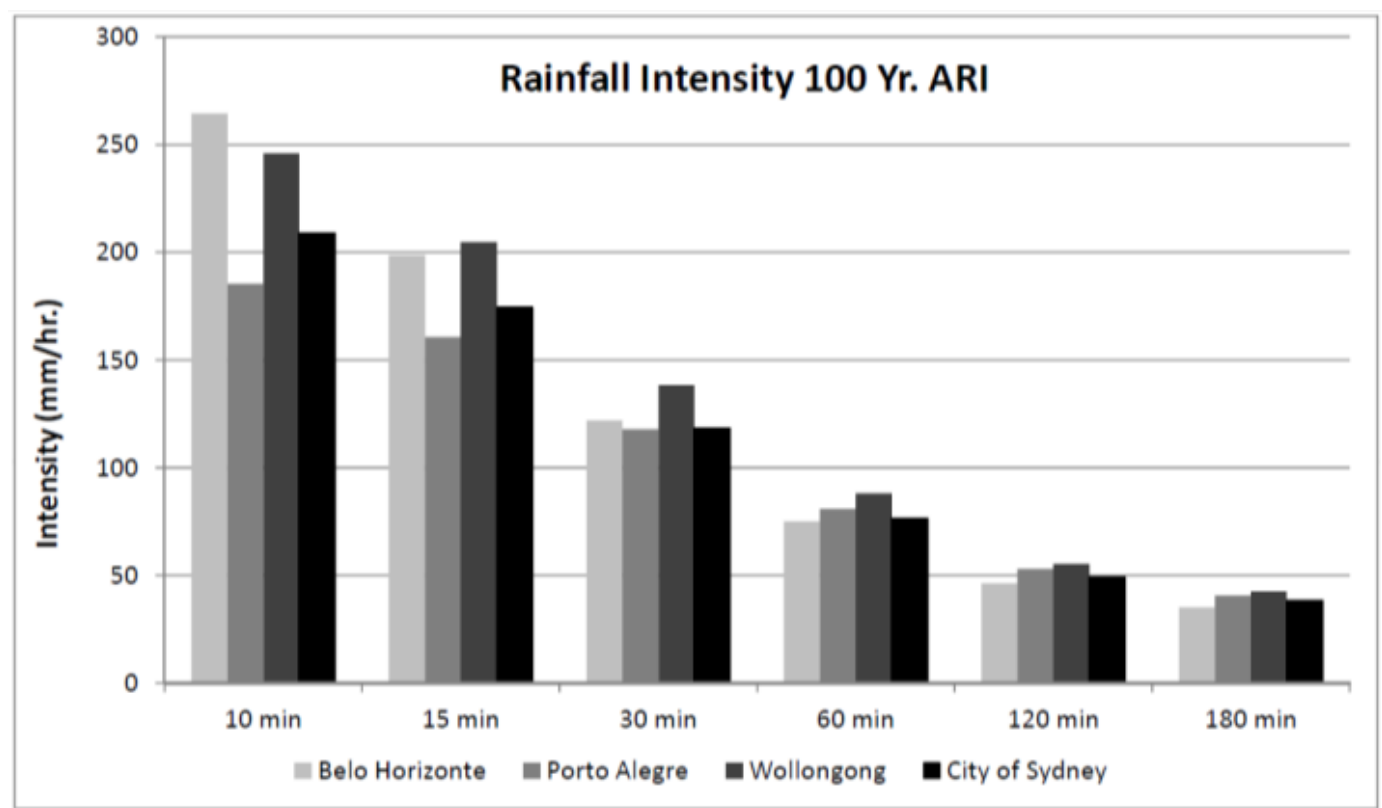

Figure 1. Comparison of rainfall intensity among the cities evaluated

\section{Comparison Performed}

The analyses presented herein were based on public documents and information provided via emails sent by management entities responsible for the OSD systems in the cities. As previously mentioned, the comparisons were performed on the differences between regulations, technical details and management matters.

Information on definition of OSD policy assessed were related to (i) the developments types where the construction of OSD is required, (ii) cases of exemption for OSD construction and (iii) the existence of incentives for the use of another source control technique to complement the OSD. In the case of policy requirements to build OSD, predications were verified for each type of development (single dwelling, multiresidential, commercial and industrial).

In technical details of OSD design guidelines were analyzed (i) the types of approaches adopted (on-site scale or catchment scale), (ii) the design methods used, (iii) the design storms adopted, (iv) the discharge devices recommended and (v) the protection against blockage proposed. Regarding the types of approaches, it was considered that on- 
site scale approach evaluate only the performance of the local drainage system, while catchment scale approach assesses the functioning of the basin drainage system, where is the development.

OSD systems management was appreciated in short and long term aspects. Information was obtained mainly through emails answered by municipal systems managers and public documents. Managers of the two Brazilian cities and eleven councils in the Sydney Metropolitan Area (Blacktown, Burwood, Campbeltown, Canada Bay, City of Sydney, Hunter's Hill, Manly, Strathfield, Sutherland Shire, Warringah and Woollahra) sent the OSD information required for this research in September 2016 and the analysis of the responses was carried out until November 2016.

In short-term management, the stages of the project approval process and OSD construction were verified, while in long-term management the inspections of the conditions of the structures and the control of the number of existing units were evaluated. Also, it was verified if in the cities occurs the seven major impediments to sustainable urban stormwater management identified by Roy et al. (2008): (1) uncertainties in performance and cost, (2) insufficient engineering standards and guidelines, (3) fragmented responsibilities, (4) lack of institutional capacity, (5) lack of legislative mandate, (6) lack of funding and effective market incentives, and (7) resistance to change.

\section{Results and Discussion}

\section{OSD Policies}

The comparison of OSD policies demonstrated that in terms of maintaining the postdevelopment flow rates the same as in the pre-development condition, Belo Horizonte has the most permissive policy, demanding stormwater source control only in development with large impervious areas. According to Belo Horizonte municipal law 
$\left(n^{\circ} 9,959 / 10\right)$, the OSD must be built only in developments which do not respect the minimum permeability rate:

- $10 \%$ of permeable area for lots with an area less than $360 \mathrm{~m}^{2}$; and

- $20 \%$ of permeable area for lots with an area greater than $360 \mathrm{~m}^{2}$.

In contrast, Porto Alegre policy is similar to Australian municipality regulations, requiring the damping of peak flow in all new developments with impervious area, except to single dwelling or developments with less than $600 \mathrm{~m}^{2}$. In both Brazilian policies, cases of exemption for OSD construction are related with the type or size of the developments. No exemption cases are defined to developments located in a flood prone area or which do not cause adverse effects to the downstream area. This indicates that the performance of the catchment drainage system was not considered at the time of policy formulation.

The Wollongong policy is stricter than Porto Alegre, requiring the use of OSD in every new development and in reforms of existing developments. Cases of OSD exemption are for development with impervious areas less than $100 \mathrm{~m}^{2}$ and other specific situations.

In the Sydney Metropolitan Area, only the North Sydney Council does not have a policy demanding the use of OSD. However, other Sydney councils have different policies to require the OSD construction, especially regarding single dwellings. Most DCPs of Sydney Councils define exemptions for OSD construction in residential developments with a limit of impervious area. Besides that, developers can be free of OSD requirements when the site is located in a flood prone area, stormwater discharge from the site will not enter the stormwater drainage system, stormwater from the site does not result in adverse downstream effects or the development uses another stormwater source control technique instead of OSD. 
The construction of OSD in developments located in a flood prone or downstream area can be ineffective. Also, it can make the situation worse if a critical event occurs and the water from OSD has no way out.

Regarding the use of an additional source control technique to complement the OSD, the Porto Alegre policy stands out in Brazil for making it possible to reduce the OSD volume in developments which adopt permeable pavements, infiltration trenches or connect the roof gutters to permeable surfaces. In general, all Sydney councils and Wollongong city recommend the use of stormwater source control measures in new developments. Some encourage the adoption of other source control techniques (absorption systems or rainwater tanks), providing a reduction in the OSD volume.

One of the problems in adoption of OSD is that the system does not provide a reduction of stormwater volume after urbanization, thereby increasing the amount of water in the rivers. The incentive to use infiltration source control techniques is the best way to preserve the site hydrologic balance, providing a reduction of runoff to the urban drainage system. This was confirmed in the study performed by Petrucci et al. (2013). They made a comparison of simulations between stormwater source control policies based on flow-rate, when it is imposed a unique value of admitted flow-rate from parcels, and limiting runoff volume, when it is prescribed a volume that must be treated at the parcel-scale without sending it to sewer network. Petrucci et al. (2013) observed that the same peak flow values can be obtained in both regulations. However volume regulations have flow-frequency curves always lower than reference, while flow-rate regulations have different effects for low and high frequencies. Also, in terms of preservation of receiving waters, the volume regulations results were better in the indicators related to fraction of time during which a flow is detected at the out-let and runoff volume bypassing treatment. 
In this way, Botany Bay, Rockdale, Ku-ring-gai and Manly councils in Sydney Metropolitan Area have interesting policies, demanding the construction of OSD only in areas where the On-site Stormwater Retention (absorption) systems are not possible. In 10 Sydney councils (Canada Bay, Hornsby, Kogarah, Lane Cave, Leichhardt, Parramatta, Randwick, Sutherland, Waverley and Woollahra), it is possible to reduce the OSD volume by also using an infiltration source control technique.

O'Loughlin et al. (1998) stated that the use of on-site water supply and recycling systems was growing in Australia. Although there had been proposals, Councils had refused to accept rainwater storage as part of a property's OSD storage requirement. However, it seems that 11 councils (Auburn, Canterbury, Holroyd, Hornsby, Lane Cave, Marrickville, Mosman, Ryde, Sutherland, Warringah and Willoughby) have changed their position, making it possible to have new developments with decreased OSD volumes installing a rainwater tank. In some aspects this may be good, considering there will be a reduction in the consumption of treated water, but the volume reduction can compromise the OSD performance. It is important in OSD design to ensure that there is sufficient volume to promote the peak flow damping.

\section{Technical Details}

Regarding to technical criteria, Brazilian cities have a site-based approach, analyzing only on-site system drainage. This approach is criticized for not evaluating impacts on urban drainage systems, and in rare cases may cause the increase of peak flows downstream.

Currently, OSD projects are approved by two public agencies in Belo Horizonte; these are the Smaru (Municipal Adjunct Secretariat of Urban Regulation) which is involved when development is exempt from environmental license requirements, and

Sudecap (Superintendence for Capital Development) which is involved if an 
environmental license is required for development to proceed. If Smaru approval is required, only the OSD volume is considered and it must meet the requirements outlined in municipal law $(9,959 / 10)$, using a Site Storage Requirement (SSR) of 300 cubic meters per hectare of area which exceeds the limit of impervious area. When an environmental license is demanded, developers need to provide a hydrologic study for OSD design, using Rational and Puls Methods, adopting the rainfall intensity of a 10 year ARI storm (Average Recurrence Interval storm).

In the city of Porto Alegre the values of $20.8(\mathrm{~L} / \mathrm{s} / \mathrm{ha})$ for Permissible Site Discharge (PSD) and $425\left(\mathrm{~m}^{3} / \mathrm{ha}\right)$ for Site Storage Requirements (SSR) are used in OSD design for developments with areas smaller than 100 hectares. These values were determined in the analysis made using McCuen formula (1989) and a 10 year ARI storm.

The city of Wollongong and the majority of the Sydney Councils adopted a catchment-based approach, requiring the use of PSD and SSR values based on analysis of entire catchments in hydrograph-producing computer models. Most Australian councils demand the use of a range of storms up to 100 year ARI in OSD design, to dampen the peak flow increased by impervious areas. However, only a few DCP councils detail the construction of a two-stage outlet, e.g., the Parramatta Council requires consideration of 1.5 and 100 year ARI storms and Wollongong Council demands considering 5 and 100 years ARI storms. The basis for requiring consideration of more frequent storms is that runoff from new developments can result in damage to watercourses and disturbance to aquatic habitats and from a sustainability viewpoint, it would be desirable to have the stormwater runoff from these newly developed sites more closely mimic pre-development conditions (UPCRT, 2005).

One of the most important aspects of OSD design is the outlet orifice. Guidelines from Brazilian cities recommend adoption of an outlet device consisting of a tube with a 
commercial diameter. However, only Porto Alegre recommends analysis of the outlet tube as an orifice or nozzle, using different discharge coefficient values. In contrast of these recommendations, Drumond et al. (2014) demonstrated that the outlet tube can also operate as a short pipe. The guidelines from the Sydney and Wollongong Councils detail the outflow control by a machined orifice at the center level of a stainless steel plate ( 3 mm thickness); this arrangement would be classified as an orifice.

Another OSD design issue is the likelihood of the outlet being blocked by debris. In the Belo Horizonte Specifications (2008) it is suggested that a sand box should be constructed before the OSD. The Porto Alegre Manual (2005) recommends installation of a grid after the inlet pipe to the OSD. The majority of Australian Councils demands the use of a mesh screen upstream of the outlets to protect against blockages and the installation of sump pumps at the outlet, to avoid turbulence near the pit floor which affects the hydraulic performance of the orifice.

Also, Brazilian and Australian municipalities require a minimum diameter for outlet devices to reduce the likelihood of blockage. However, the values (e.g. 65 or 75 mm) considered in five Sydney Councils (Ashfield, Campbeltown, Sutherland, Strathfield and Willoughby) and Belo Horizonte may not provide sufficient restriction for damping of the peak flow, as demonstrated by Drumond (2012). A summary of requirements in the different cities is shown in Table 1.

Table 1. Summary of technical details required in OSD design

\begin{tabular}{|l|c|c|c|c|}
\hline \multicolumn{1}{|c|}{ Parameter } & $\begin{array}{c}\text { Belo } \\
\text { Horizonte }\end{array}$ & Porto Alegre & Wollongong & Sydney \\
\hline Approach & On-site scale & On-site scale & $\begin{array}{c}\text { Catchment } \\
\text { scale }\end{array}$ & $\begin{array}{c}\text { Catchment } \\
\text { scale }\end{array}$ \\
\hline Design method & $\begin{array}{c}\text { Rational and } \\
\text { Puls method } \\
\text { (Sudecap) } \\
\text { SSR value } \\
\text { (Smaru) }\end{array}$ & $\begin{array}{c}\text { PSD and SSR } \\
\text { values }\end{array}$ & $\begin{array}{c}\text { PSD and SSR } \\
\text { values }\end{array}$ & $\begin{array}{c}\text { PSD and SSR } \\
\text { values }\end{array}$ \\
\hline
\end{tabular}




\begin{tabular}{|l|c|c|c|c|}
\hline Design Storm & 10 year ARI & 10 year ARI & $\begin{array}{c}5 \text { and } 100 \text { year } \\
\text { ARI }\end{array}$ & $\begin{array}{c}\text { From } 1.5 \text { to } \\
100 \text { year ARI }\end{array}$ \\
\hline $\begin{array}{l}\text { Discharge } \\
\text { device }\end{array}$ & Tube & Tube & Orifice & Orifice \\
\hline $\begin{array}{l}\text { Protection } \\
\text { against } \\
\text { blockage }\end{array}$ & Sand box & $\begin{array}{c}\text { Grid in the } \\
\text { OSD entrance }\end{array}$ & $\begin{array}{c}\text { Mesh screen } \\
\text { prior to orifice }\end{array}$ & $\begin{array}{c}\text { Mesh screen } \\
\text { prior to orifice }\end{array}$ \\
\hline $\begin{array}{l}\text { Minimum } \\
\text { diameter }\end{array}$ & $75 \mathrm{~mm}$ & - & $50 \mathrm{~mm}$ & $\begin{array}{c}\text { From } 25 \text { to } 75 \\
\mathrm{~mm}\end{array}$ \\
\hline
\end{tabular}

The comparison above shows the differences of approaches and methodologies adopted in OSD designs among municipalities. However, a lack of research regarding the real performance of OSD already built does not allow for determining which approach is best. It is necessary to investigate OSD performance in a real situation, assessing the damping of peak flow, maintenance issues throughout its useful life, blockage problems with debris and the parameters related to its dimensioning.

\section{Management Matters}

In both Brazilian cities, the OSD construction process is carried out with the approval of the OSD project submitted by the developer. The inspection is performed by employees of the public agency, responsible for managing the drainage system.

Australian municipalities usually do not perform OSD inspections after final approval of its construction, unless there is an issue of flooding or ineffectiveness of the OSD. Australian Councils require an engineering certificate which describes that the OSD was properly constructed.

In all municipalities, the site owner is responsible for OSD maintenance and cleaning. One of the reasons to not do the inspections, informed by managers of municipal systems, is the lack of employees. In many municipalities, there are a few people working in the approval process of development and they do not evaluate only the urban drainage projects. 
Another problem is to guarantee the system's continued operation over the entire life of the development. Wollongong and some Sydney Councils solved this problem by requiring, prior to the issue of final acceptance, a restriction on the use of the land and a positive covenant over the lot in favour of the local council. Belo Horizonte has an interesting management of OSD inspections in cases in which an environmental license is required. When the operating license expires and the developer requires renewal, the OSD condition is checked. Unfortunately, the license time is long, varying between 4 and 10 years.

In the case of OSD already built, only the public agency of Porto Alegre informed the approximate number of units in the city (1,059 units). The lack of information about OSD built in the municipalities indicates negligence in the system management.

This negligence was verified in the study made by Roy et al. (2008), which identified seven major impediments to sustainable urban stormwater management. In assessment of OSD systems management in Australian and Brazilian cities, most of these problems described by Roy et al. (2008) were found.

In general, Australian cities have more detailed OSD engineering guidelines than Brazilian cities. Despite theoretical detail, uncertainties in the OSD performance still remain, since very few studies were conducted on the operation of OSDs already implanted.

Fragmented responsibility is another problem in management of stormwater runoff in Australia, according to Roy et al. (2008). Multiple entities are often responsible for management of a single catchment. In Sydney, the city council shares in OSD management with Sydney Water. As previously mentioned, Belo Horizonte also has a fragmented OSD management, where two public agencies approve the OSD projects using different criteria. 
Another problem is the importance given by politicians to urban drainage systems. In Brazil, governing bodies do not consider improvement to drainage systems as a priority, but these issues are only remembered when flooding problems occur.

The lack of studies on OSD systems help maintain the resistance to change of some decisions makers. It is for this reason that some engineers are still skeptical regarding the use of OSD.

\section{How OSD performance could be better evaluated}

As Barbosa et al. (2012) described, hydrological data monitoring is essential to characterize a stormwater event or to calibrate the simulation model. Computer simulations of urban drainage systems should be developed with OSD monitoring data on a real scale. To better understand the OSD performance, it is necessary to monitor the whole system, including rainfall, water level inside the OSD, inflow and outflow. To carry out these measurements, there will be necessary to install a rain gauge at the site, a flow measuring equipment at inlet and outlet and a water level sensor inside the OSD.

In order to clarify the uncertainties about OSD applications, new monitoring studies should be performed on a site scale to obtain more in-depth knowledge on aspects of (i) improving representation of the rain transformation into flow; (ii) checking OSD performance in the real rainfall events; (iii) setting the volume needed for damping; (iv) evaluating the discharge coefficient values; (v) getting the runoff coefficient values for different storms; (vi) examining the need for maintenance and clogging problems over their lifetime. Also, using the monitoring data, it could be possible make comparisons among different technical criteria and to define a better method to design OSD.

Another research could monitor simultaneously the OSD performance at the site scale and the outflow in the catchment, evaluating the real benefits at a catchment scale. These studies may be helpful to improve the urban drainage management at the operating 
site, through the development of techniques related to the installation of equipment to measure the amount of water released into the drainage system.

Innovative performance methodologies could also be created to record the on-site stormwater discharge into the public system, or even register only if stormwater is passed through the spillway. In the first situation could be used a flow-meter installed in a outlet

pipe, as proposed by Maheepalla et al. (2001). In the second case, the passage of stormwater through the OSD spillway could indicate problems with the flow restriction, especially if there is not a critical rainfall event. The measurements could be made using a water level sensor installed inside the OSD.

\section{Conclusion}

The comparison of OSD policies among Australian and Brazilian cities indicated the differences in requirements and technical approaches that exist in both countries. Australian OSD design guidelines are a few steps ahead of Brazilian manuals in terms of project details. The Australian guidelines require the damping of flows generated with storms up to 100 years ARI and demands the use of at least two discharge structures. Brazilian cities manuals adopt the use of only one storm with 10 years ARI to design the OSD with one discharge structure. Another important difference is the use in Australia of an orifice plate in the discharge devices, while in Brazil are used commercial tubes. However, it is not possible to affirm that the catchment-based approach, adopted by most Australian Councils, is better than the site-based approach, embraced by Brazilian cities, since neither is supported by monitoring data of real OSD performance.

In general, all municipalities have the same management problems. There is no control over the number of OSDs constructed in the cities or even the conditions of the systems, since rarely the cities do inspections. Therefore, urban drainage managers do not know if site discharge is occurring properly in the public system. 
It is therefore necessary to develop new research, especially on a site scale, monitoring the OSD systems, in order to check their performance, efficiency of the peak flow damping, maintenance, clogging problems throughout their useful life and parameters related to the methods used in its design.

\section{Acknowledgements}

The authors wish to thank Universidade Federal de Minas Gerais - UFMG, University of Technology Sydney - UTS, CNPq - Conselho Nacional de Desenvolvimento Científico e Tecnológico (Chamada Universal - MCTI/CNPq Nº 14/2014), FAPEMIG - Fundação de Amparo à Pesquisa do Estado de Minas Gerais and CAPES - Coordenação de Aperfeiçoamento de Pessoal de Nível Superior for their financial support.

\section{References}

Agra, S. G., 2001. Estudo Experimental de Microrreservatórios para o Controle do Escoamento Superficial. Dissertation (MsC) Universidade Federal do Rio Grande do Sul, Brazil.

Baptista, M.B., Nascimento, N. de O. e Barraud, S. Técnicas compensatórias em Drenagem Urbana. 1. Ed. Porto Alegre: ABRH, 2005. 266 p.

Barbosa, A. E., Fernandes, J. N., David, L. M., 2012, Key issues for sustainable urban stormwater management. Water Research Journal 46 (2012) 6787 e 6798.

Belo Horizonte City. Law No. 7,166 of August 27, 1996.

Belo Horizonte City. Law No. 9,959 of July 20, 2010.

Belo Horizonte City, 2008. Caderno de encargos: SUDECAP. Diretoria de Planejamento e Gestão - 3rd edition - Belo Horizonte: Sudecap, 2008.

Cabral, J. J. S. P., Cartaxo, A. L.; Antônio, A. C. D. Borba Filho, B. F. L.; Santos S L. L., Microrreservatório de detenção em logradouro público. In: Righetto, A. M. (coord.). Manejo de águas pluviais urbanas. Rio de Janeiro: ABES, 2009. cap. 7, p. 256-286.

Campos, J. B. N., 2007. Análise hidrológica experimental de lotes urbanos sob formas diferenciadas de ocupação e controle da inundação. Dissertation (MsC). Universidade Federal de São Carlos, Brazil.

Da Silva, P. O., Cabral, J. J. S. P., 2014. Atenuação de Picos de Vazão em Área Problema: Estudo Comparativo de Reservatórios de Detenção em Lote, em Logradouros e em Grande Área da Bacia. RBRH - Revista Brasileira de Recursos Hídricos, Volume 19 n.2 p. 7-18, Abr/Jun 2014.

Drumond, P. P., Coelho, M. M. L. P., Moura, P. M, 2011. Análise do volume de reservação de águas pluviais em lotes: comparação do caso de Belo Horizonte com outras cidades brasileiras. In: XIX Simpósio Brasileiro de Recursos Hídricos, ABRH, Maceió, 20 pages. 
Drumond, P. P., 2012. Estudo da influência da reservação de águas pluviais em lotes do município de Belo Horizonte, MG: Avaliação hidráulica e hidrológica.

Dissertation (MsC) Universidade Federal de Minas Gerais - Brazil.

Drumond, P. P., Coelho, M. M. L. P., Moura, P. M., 2014. Valores de coeficiente de descarga em tubos de saída de microrreservatórios. RBRH - Revista Brasileira de Recursos Hídricos, Volume 19 n.2 p. 267-280, Abr/Jun 2014.

Drumond, P. P.; Moura, P. M.; Coelho,M. M. L. P., 2018. Comparison the monitoring data of an on-site stormwater detention (OSD) and the results in the use of theoretical methods for its design. RBRH- Revista Brasileira de Recursos Hídricos, Volume 23, n. 18 , p. 1-12.

Emerson, C. Welty, C., Traver, R. 2005. Watershed-scale evaluation of a system of storm water detetion basis. Journal of Hydrologic Engineering. 10, 237

Faulkner, B., 1999. The control of surface water runoff from new development - UK national 'policy' in need of review? Urban Water J. 1, 207-215.

Fletcher, T.D., Andrieu, H., Hamel, P., 2013. Understanding, management and modelling of urban hydrology and its consequences for receiving waters: a state of the art. Adv. Water Resources 51, 261-279.

Fletcher, T.D., Shuster, W., Hunt, W.F., Ashley, R., Butler, D., Arthur, S., Trowsdale, S., Barraud, S., Semadeni-Davies, A., Bertrand-Krajewski, J.-L., 2014. Suds, lid, bmps, wsud and more-the evolution and application of terminology surrounding urban drainage. Urban Water J. 12 (7), 525-542.

Goff, K., Gentry, R., 2006. The influence of watershed and development characteristics on the cumulative impacts of stormwater detention ponds. Water Resources Management 20, 829-860.

Kelly, H. G., Bryck, J. M. R., 1987. Understanding the Use of Detention Storage in Stormwater Management: A British Columbia Perspective, Canadian Water Resources Journal, Vol. 12, $\mathrm{N}^{\circ} 1$.

Konrad, C. P., Burges, S. J., 2001. Hydrologic mitigation using on-site residential storm-water detention. Journal of Water Resources Planning and Management, 127, p. 99-107.

Li, C., Fletcher, T. D., Duncan, H. P., Burns, M. J. (2017), Can stormwater control measures restore altered urban flow regimes at the catchment scale? Journal of Hydrology 549 (2017), 631-653.

Maheepalaa, U., Takyib, A., Perera, B., 2001. Hydrological data monitoring for urban stormwater drainage systems. Journal of Hydrology 245 (1e4), 32e47.

McCuen, R. H., 1979. Downstream effects of stormwater management basins. Journal of the Hydraulics Division ASCE 105, 1343-1356.

McCuen, R.H. Hydrologic analysis and design. Englewood Cliffs, New Jersey: Prentice Hall, 1989. 867p.

O’Loughlin, G., Beecham, S., Lees. S., Rose, L. and Nicholas, D., 1995. On-site Stormwater detention systems in Sydney. In: Novatech 95, Lyon, 8 pages.

O’Loughlin, G., Hguyen, V., Bewsher, D., Lees, S., 1998. Refining on-site stormwater detention practice in Sydney. In: International Conference on Innovative Technologies in Urban Storm Drainage - Novatech, 1998, Lyon, 8 pages. 
Petrucci, G., Deroubaix, J. F., Bompard, P., Deutsch. J.C., Gouvello, B., Laffréchine, K. E Tassin, B., 2010. Efficiency of distributed water harvesting on runoff reduction. Case-study of "Village Parisien" district, Champigny-sur-Marne, Ile de France. In: 7th International Conference on Innovative Techonologies in Urban Storm DrainageNOVATECH, Lyon.

Petrucci, G., Rioust, E., Deroubaix, J., Tassin, B. (2013), Do stormwater source control policies deliver the right hydrologic outcomes? Journal of Hydrology 485 (2013), 188-200.

Piel, C., Perez, I., Maytraud, T., 1999. Three examples of temporary stormwater catchments in dense urban areas; a sustainable development approach. Water Science and Technology J., v. 39, n 2, p. 25-32.

Porto Alegre City. Municipal Ordinance 15,371 of 17 November, 2006.

Porto Alegre City. Municipal Ordinance 18,611 of 9 April, 2014.

Porto Alegre City, 2005. Plano Diretor de Drenagem Urbana, Manual de Drenagem Urbana. Porto Alegre: IPH.

Ronalds, R., Zhang, 2017. H., An alternative method for on-site stormwater detention design. Journal of Hydrology (NZ) 56 (2), p 137-154.

Roy, A.H., Wenger, S.J., Fletcher, T.D., Walsh, C.J., Ladson, A.R., Shuster, W.D., Thurston, H.W., Brown, R.R., 2008. Impediments and solutions to sustainable, watershed-scale urban stormwater management: lessons from Australia and the United States. Environmental Management 42, 344-359.

Schilling, W. 1982. Cisterns against storms. In: Featherstone, R. E., James, A. Urban systems drainage. London: Computational Mechanics Centre. p. 4.49-4.60.

Silveri, P., Rigby, T., 2006. Experiences in Developing an Upgraded OSD Policy for the City of Wollongong. In: 30th Hydrology and Water Resources Symposium - 2006, Launceston, 7 pages.

Sugio, S., Deguchi, C., Kunitake, M. Suharyanto, A., Yamakawa, Y. 1995. Use of house storage to decrease and delay te peak point in stormwater discharge from small urbanized basin. In: International Conference on Innovative Technologies in Urban Storm Drainage, 2., 1995, Lyon. Graie.

Tassi, R., 2002. Efeito dos microrreservatórios de lote sobre a macrodrenagem urbana. Dissertation (MsC) - Instituto de Pesquisas Hidráulicas. Universidade Federal do Rio Grande do Sul, 156 p.

Todeschini, S., Papiri, S., Ciaponi, C., 2012. Performance of stormwater detention tanks for urban drainage systems in northern Italy. Journal of Environmental Management, 101, p. 33-45.

Tsuchiya, A., 1978. Evaluation of on-site stormwater detention methods in urbanized areas. In: HELLIWELL, P. R. Urban Storm Drainage. London: Pentech Press. p. 470478.

UPRCT - Upper Parramatta River Catchment Trust 2005, On-Site Stormwater Detention Handbook, $4^{\text {th }}$ Edition, Parramatta, NSW, Australia.

Urbonas, B. R., Glidden, M.W., 1983. Potential effectiveness of detention policies. In: Southwest Storm Drainage Symposium. Texas A\&M, November 1983. 
Wollongong City Council, 2009. Chapter E14: Stormwater Management Part EGeneral Controls - Environmental Controls, Development Control Plan.

Wollongong, NSW, Australia. 